\title{
A HISTORICAL NARRATIVE AND CRITICAL ANALYSIS OF THE ROOTS AND CAUSES OF CONFLICT IN THE SOUTHERN PHILIPPINES
}

\author{
Jerson Benia Narciso, \\ Inter Religious Studies, Graduate School, Gadjah Mada University \\ and \\ Central Philippine University Email: \\ jersonarsica@yahoo.com \\ Fatimah Husein \\ State Islamic University Yogyakarta \\ Bernard Adeney Risakotta \\ Christian Duta Wacana University Yogyakarta
}

\begin{abstract}
ABSTRAK
Tulisan ini menyoroti kronologi peristiwa sejarah yang signifikan sejak pra-kolonial hingga saat ini yang telah memberikan kontribusi terhadap konflik di Filipina Selatan. Tulisan ini juga menjelaskan dan menganalisa akar dan penyebab konflik dan bagaimana hal ini sudah diajukan pada saat itu baik oleh pemerintah Filipina dan kelompok-kelompok pembebasan Islam yang berbeda yang merupakan aktor dan pemain utama dalam konflik.

Tulisan ini menggunakan kedua analisa historis dan struktural untuk memperoleh gambaran yang lebih luas dan lengkap dari sejarah serta realitas sosial-politik, budaya, dan ekonomi yang berkuasa di Filipina Selatan. Studi ini menunjukkan bahwa masalah konflik di Mindanao cukup kompleks dan rumit. Dengan demikian, ia memerlukan pemahaman yang lebih luas dan hati-hati dalam menganalisa masalah, serta solusi yang dapat disepakati oleh kelompok dan faksi-faksi yang bertarung menuju pendekatan damai dan negosiasi bagi proses perdamaian Mindanao.
\end{abstract}

Kata kunci: Akar konflik, Penyebab Konflik, Philipina Selatan, Narasi Historis, Analisis Kritis

\begin{abstract}
This paper highlights the chronology of significant historical events, from pre-colonial times to the present, which have significantly contributed to the conflict in Southern Philippines. It also describes and analyzes the roots and causes of the conflict and how these are being addressed at the moment, both by the Philippine government and the different Islamic liberationist groups which are the main actors and players in the conflict.

This paper employs both historical and structural analysis to obtain a much broader and complete picture of the historical, socio-political, cultural, and economic realities reigning in the southern Philippines. The study shows that the problem of conflict in Mindanao is complex and complicated. Thus, a much broader and careful understanding and analysis of the problem, as well as solutions that can be agreed upon by contending groups and factions toward a peaceful and negotiated approach to the Mindanao peace process, are required.
\end{abstract}

Keywords: Root of conflict, Cause of conflict, Southern Philippines, Historical Narrative, Critical Analysis. 


\section{INTRODUCTION}

The armed conflict in Southern Philippines has continued for more than four centuries and is considered one of the world's "longest" and "bloodiest" running armed conflicts (Philippine Free Press, May $27,2000)$. It is also known as the "largest and most persistent armed conflict in Southeast Asia." It resulted in the destruction of properties and livelihood, displacement of thousands of families, deaths of thousands of combatants from both sides, and innocent civilians including women and children killed in the crossfire (Tan in Krishna and Tan, 2003: 98).

The conflict is also damaging the country's image and creates the impression that the Philippines is a virtual war zone and a "haven" for "terrorists" and "insurgents," thus contributing tremendously to the political and economic instability of the country. The global "War on Terror" spearheaded by the Bush administration has encouraged prejudice and discrimination against Muslim communities who are labeled "terrorists." For example, the governments of Canada, Australia, New Zealand, the United Kingdom, and the United States have made periodic advisories that restrict travel of their citizens to Mindanao for "security" reasons (American Chamber of Commerce of the Philippines, 2003).

This study is aimed towards critical understanding of the historical, sociopolitical, cultural and economic factors that contribute to the violent conflict in Southern Philippines and how the roots and causes of this conflict are being addressed at the moment both by the Philippine government and the different liberationist groups who are the main actors in the conflict.

\section{DISCUSSION}

\section{Brief Historical Sketch of the Conflict}

The conflict in Southern Philippines has a long and deep-seated historical root that goes back to the Spanish and American colonial period. Islam started to spread in the Philippine archipelago in the late $14^{\text {th }}$ century and began to take root and interwoven into the indigenous customs and traditions of the Moros. Thus, when the Spaniards arrived in the early part of $16^{\text {th }}$ century (1521), the Muslims were already an established sovereignty, and Islam had already gained wide acceptance among the inhabitants of Mindanao, Sulu, Tawi-Tawi and Palawan (Majul, 1999: 78; Osais and Lorenza, 1931: 139; Laubach, 1925: 57). Gowing notes that shortly before the Spaniards came, Islam had already reached Manila and had gained prominence in some parts of Luzon. Manila was then ruled by Rajah Sulayman and his uncle Lakandula, who were relatives of the Sultan of Brunei (Gowing, 1983: 8-10).

The Spaniards were able to Christianize almost all parts of Luzon and the Visayas in a short span of time but were met with strong and bloody resistance in Mindanao. In their attempts to subjugate and colonize the entire Mindanao, the Spaniards enlisted many of their Christian converts as "mercenary" soldiers to fight against the Moros in the South (Canoy, 1987: 30). The perceived "connivance" and support of Christianized Filipinos of the Spaniard's conquest of Mindanao had angered many Muslims and worsened the gap between them (Isidro and Saber, 1967: 36-37).

During the American occupation (18991946), the conflict between Christians and Muslims had become more intense. The American policy towards the Moros was at first congenial and accommodating. In trying to avoid getting meshed up in the conflict that the Spaniards had already created between Christians and Muslims, the Americans had adopted a "non-interference" policy towards the Moro affairs by acknowledging the protocols and agreement signed in the 1878 treaty between the Sulu Sultanate and Spain. 
However, when met with fierce resistance from the Moros who strongly refused to be subjugated, the Americans decided to unilaterally revoke the treaty, enforced stricter laws and policies towards the Moros and started to employ military force to rule the Moroland (Mendoza, 1999: 3-6).

This drastic move by the Americans caused serious disruption in the Moro sociopolitical structure. The Muslims felt cheated because although they were not subdued by the Spaniards they were included in the sale of the Philippines to America by virtue of the Treaty of Paris. The Treaty of Paris was an agreement signed between the Spaniards and the Americans when the Spaniards finally turned over the control of the Philippine archipelago to their American successors. The Muslims then were forced to be integrated to the mainstream Philippine politics, thus, lumped into one group with two distinct cultures. Ben Alforque describes this process as "the merging of conflictive history and the integration of the opposites" (Alfourque, 2001).

The Moro resistance was weakened by years of bloody confrontations which subsequently led to the introduction of the American system of government and the speedy integration of the Moros into a united, self-governing Philippines. In the early 1900s, Christianized Filipino natives were encouraged to migrate to Moroland under the catchword, "Mindanao, the land of promise" (Gowing and McAmis, 1974: 54). This resulted in more violent confrontations between Christians and Muslims in Mindanao. Christianized Filipinos were also given increasing powers in the administration of the Moro land.

By 1916, the newly organized and fully "Filipinized" Philippine Legislature assumed legislative control over Mindanao and Sulu. Domestic matters in Moro land were put under the control of Christianized Filipinos (Man, 1990: 55). This transmigration program and turning over of control to Christian migrants have altered ethnic, cultural, religious, economic and political balance in
Mindanao. It also engendered a deep sense of resentment that was continuously fed by integrationist policies that have largely ignored Islamic cultural, religious and political traditions (Costello, 1992: 40-41).

After the Second World War, Christian migration to Mindanao became more rapid. The gap between Christians and Moros was widened as Christian Filipinos gained more access and benefits to education and economic opportunities. Christians began to dominate the economic and political spheres even in some predominantly Moro areas. Tan points out that between 1950-1960, Christian business men, industrialists, loggers and politicians in collaboration with Moro elites dispossessed Moros and lumads of their lands through title frauds, tedious application procedures, and costly legal processes.

As a result, the Muslims who held 98 percent of the lands in Mindanao and Sulu before the turn of the $20^{\text {th }}$ century, ended up in 1976 owning less than 17 percent, mostly remote and infertile land (Mercado, 2009: 224225). Exploitative economic activities which have mainly favored Christian migrants, have exacerbated disparities and further fueled feelings of alienation and deprivation among Muslims (Islam, 1998: 452). It was against this socio-political and economic context that the revolutionary separatist Islamic movements began to rise and fought against the Philippine government (Mitsuo et.al, 2001: 118-119).

From 1965 to 1971, political organizations composed mostly of Moro students began to rise and waged numerous campaigns for the recognition of the Moro's rights for self-determination as a people with distinct history and identity. The movement resulted in the establishment of the first Muslim revolutionary group, the Moro National Liberation Front (MNLF) founded by young Muslim activists headed by Nur Misuari, a professor at the University of the Philippines (Dalupan, 2005: 233). MNLF was founded on egalitarian ideology which is characterized by a principled belief in the equality of all people in the political, economic, social 
and civil realms regardless of differences in religion, race, ethnic origin and gender.

The main goal of the MNLF is to achieve independence of the Bangsamoro Land which includes Sulu, Mindanao and Palawan, or otherwise known as MINSUPALA. In 1970, MNLF proclaimed itself as a political party composed of "freedom fighters" (otherwise known as the Bangsa Moro Army) and started to launch a protracted armed struggle against the Philippine government. This resulted in violent confrontations between Christian para-military groups (backed up by the Philippine army) and the MNLF soldiers. In 1972, Marcos declared Martial Law against the growing insurgency. The implementation of Martial Law had further pushed the Bangsamoro into armed resistance (Abinales, 2000; Vitug and Gloria, 2000). The MNLF waged armed offensives and demanded recognition for an independent state for the Bangsamoro (Moro Homeland). From 1972 to 1976, military and civilian casualties reached 120, 000 (Bacani, 2005: 4).

The first peace talk between the MNLF and the Government Peace Panel was initiated in1976 through the assistance of the former Libyan leader Muamar al Gaddafi that resulted in the signing of the Tripoli agreement which tackled the Muslims' demand for an autonomous Mindanao- a concession which was hoped to end the conflict. The Tripoli Agreement provided for a general ceasefire and called for autonomy under the broad principle that Mindanao would remain an integral part of the Republic of the Philippines. Despite the signing of the Tripoli Agreement of 1976, the war still continued between the MNLF warriors and the Armed Forces of the Philippines (AFP) due to divergent interpretations and the absence of a clear guideline on the implementation of the agreement (McKenna, 1998: 165-166).

Instead of implementing the provisions of the Tripoli Agreement, Marcos went ahead and held a referendum amid Moro charges that the government's autonomy plan allowed only token self-rule. The insincerity of the dictatorial Marcos regime to implement the stipulations of the Tripoli Agreement had rendered it null and void and led to heightened wars and bloodshed. Subsequent moves by the Cory Aquino administration to arrive at an acceptable political arrangement such as the creation of the Autonomous Region of Muslim Mindanao (ARMM) had also failed to secure acceptance of the MNLF as recognized by the Philippine government the official representative organization of the Muslims in the Philippines before MILF (Nunez, 1997: 6).

The ARMM was created on August 1, 1989 by the Aquino administration to cater to the clamor for Moro autonomy. But in a plebiscite held in November of the same year, only four provinces-Lanao del Sur, Maguindanao, Sulu and Tawi-tawi out of thirteen voted to be included in the ARMM. Again, the Muslims dream for an Autonomous Muslim Mindanao did not materialize (Nunez, 1997: 7).

Under the Ramos administration, there was the signing of agreement between the Philippine government and the MNLF in September 1996 which mandated the creation of the Southern Philippine Council for Peace and Development (SPCPD). It was intended to be an innovative political solution that builds in previous peace efforts (such as the Tripoli Agreement) within the parameters of the 1987 constitution. The agreement was more than just a political solution but an economic proposition. The agreement calls for the creation of a "special zone" and development that includes 14 provinces and 9 cities in Mindanao (including Palawan). However, such areas that were made the focus of intense efforts for development did not bring any significant changes both in the political and economic condition of Mindanao (Nunez, 1997: xvi).

Nur Misuari was coopted by the government to head the SPCPD and later ran unopposed for the governorship of ARMM. However, he was accused by some revolutionary Muslim groups of having "inherited a bureaucracy that is tainted by corruption, internal wrangling 
and wastefulness (Nunez, 1997: 8). It was observed that under Misuari's leadership, the ARMM had become more economically depressed and faced enormous peace and order problems. It was also noted that during this time there was a significant increase of cases of violence in Mindanao. Muslim factionalism was seen as a major factor in the movement's decline. Differing goals, traditional tribal rivalries, and competition among Moro leaders for control of the movement produced a three-way split in the MNLF during the late 1970s. However, some Muslim sectors believe that the weakening of the MNLF revolutionary movement was the result of the government's attempts to polarize and divide Muslim communities (Dalupan in Haar and Busuttil, 2005: 235).

The first break occurred in 1977 when Hashim Salamat, supported by ethnic Maguindanaos and Maranaos, formed a separate movement- the Bangsamoro Liberation Organization (BLO), which at first advocated a more moderate and conciliatory approach toward the government. This break which gained the support of the Maranaos and Maguindanaos, the second and the third largest Muslim ethnic groups in Mindanao had significantly weakened the more militant MNLF which is predominantly supported by the Tausogs, the biggest Muslim ethnic group based mostly in Sulu, Tawi-tawi and Basilan (Dalupan in Haar and Busuttil, 2005: 235).

The founding of the BLO led to the formal establishment of the Moro Islamic Liberation Front (MILF) in 1980 with Hashim Salamat still at the helm of its leadership, as a splinter movement of the MNLF. The group is known to be more religiously oriented than its parent movement, emphasizing the promotion of Islamic ideals rather than the simple pursuit of autonomy based on nationalist objectives. The use of the term "Islamic" in the groups' name was a deliberate move intended to distinguish it from the nationalist and more secular orientation of the MNLF.

For the MILF, the core of the Bangsamoro struggle is "Islamic renewal" consisting of two interrelated components namely: Reform of Muslim political society; and religious reform. Islamic renewal is understood as "the transformation of behavior and attitudes and institutions in all levels of Moro society to harmonize them with the shariah" (Wadi, 2000). towards "revitalized" Islamic society in which a Muslim leader "stands as a symbol of the rule of Divine Law over human society. The main political aspiration of the MILF as declared by its founder, Ustadz Hashim Salamat, is the creation of a separate Islamic state in all areas where Muslims are a majority in the Southern Philippines. These areas as defined by the MILF include: Parts of the Zamboanga peninsula, Davao, Central Mindanao, Basilan, Sulu, tawi-tawi and Palawan.

This political objective of creating a separate Islamic state known as the Mindanao Islamic Republic (MIR) seeks to establish a system of government that upholds and applies Islamic law (shariah) in all aspects of daily life. This goal is to be achieved through a two-pronged program of $d a^{\prime} w a$ (preaching) and revolutionary activities (jihad) against the Philippine government (Far Eastern Economic Review, February 23, 19995; Asiaweek, April 3, 1998). Emphasizing that politics and religion are inseparable realms, the MILF gives the ulama prominent leadership and advisory roles and maintains that all its camps and military structures are also places of worship for its fighters (Gutierrez in Gaerland and Stankovitch, 2000: 152).

The second splinter group is the Abu Sayyaf ("bearer of the sword") known to be a self-styled fundamentalist insurgent movement which was founded by Abdurajak Janjalani in 1989. This group was originally known as the Mujahideen Commando Freedom Fighters (MCFF). In 1992, the MCFF was renamed the Jundullah (literally, "Servants of Allah"), and then the Abu Sayyaf Group (ASG) in 1993. The group calls itself "Al-Harakat Al-Islamiyya" or the Islamic movement (http://www.fas.org/ irp/world/para/asg.htm,date accessed: 12/ 08/11). 
It is governed by an Executive Committee headed by a Caliph and eight other religious leaders. This executive committee constitutes the so-called MINSUPALA Islamic Theocratic State Shadow Government (MIT-SG) (The Philippines NICA, 1996: 6-9). The main objective of the Abu Sayyaf is the establishment of an independent and exclusive Islamic state in Mindanao. Unlike MNLF and MILF which merely aim for independence, the Abu Sayyaf espouses violent religious intolerance, advocating the deliberate targeting of Christians in Mindanao. Its militant radicalism and extremism is directed towards the advancement of the Muslims' struggle which they believed was betrayed by the MNLF when it conceded to sign a peace agreement with the government (Abubakar in Nathan and Kamali, 2005: 54).

In terms of revolutionary political violence, virtually all of Abu Sayyaf's activities are considered by the government as terrorist in nature. Since its inception in the early 1990s, the group is known for its bombings, kidnappings, assassinations and extortion activities. All these as they claim are part of what they describe as "their fight for an independent Islamic state" (Nankivell and Bontilier, 2007: 116).

Sporadic but continues attacks of the MILF against the government troops in Mindanao had led to the declaration of a "Total War Policy" by the Estrada administration in 2000 which resulted in the suspension of peace talks, and later, to the declaration of jihad by Hashim Salamat, the chairman of the MILF against the Philippine government. This led to more violent wars and bloodshed, as the government launched all-out and massive attacks and occupation of MILF camps and as the MILF had adopted a guerilla type of warfare against the government military troops.

The Arroyo administration had earlier shown signs of hope for the resumption of peace talks as it declared a unilateral ceasefire and initiated exploratory talks with the MILF. This peace program however was short lived since the Arroyo administration had soon adopted the "all-out war" policy of the deposed Estrada administration after the negotiation of the 2001 Tripoli Peace Agreement had ended in a deadlock.

The current "Noynoy" Benigno Aquino administration has expressed willingness to give priority to the peace process in Mindanao. Earlier in his inaugural speech in June 30, 2010 published in national and international newspapers, Aquino has promised the Filipino people of genuine democracy, peace and prosperity and to eliminate widespread violence and corruption that has plagued the country for many years and pursue peace talks with MNLF, MILF and the Abusayafs. Aquino also assured the public that his administration will be "sincere in dealing with the peoples of Mindanao and will pursue a peaceful and just settlement of conflict inclusive of the interests of all-may they be Lumads, Bangsamoro or Christian" (Manila Bulletin Newspaper Online: "Noynoy Aquino's Inaugural Speech", June 30, 2010). However, while peace negotiations are going on between the government peace panel and the MILF, no substantial development has been reached yet.

As it shows, there is much work yet to be done, and unless the real roots and causes of the conflict are identified and addressed properly, peace will remain an illusive dream in Mindanao.

\section{Critical Analysis of the Roots of the Conflict}

Although armed conflict in Southern Philippines has been going on for decades, the roots and causes of this conflict is not generally well understood. Over the years, with the changing socio-political and cultural situations in Mindanao, the conflict has become more complex and complicated. Nevertheless, in spite of its complexities, in general, the roots of the armed conflict can be described in the following categories: 


\section{Political}

It is important to take note that before the arrival of theSpaniards, the Bangsamoro people were already in the process of state formation, and Islamic Institutions were already in place such as, mosques, religious schools and the political concept of sultanate (LaRousse, 2001: 44). Samuel K. Tan notes that the Muslim political structure consisted of two levels: the power elite and There are no sources in the current document.Muslim masses. Authority was vested in a ruling elite of datus, sultans and other local oligarchies, while responsibility was exercised by the rest of the Muslim people. A council of elders (ruma bichara) advised the ruling class which bred autocratic rule. The activities of the community were therefore dictated by the interests of the elite. The datus and sultans inspired raids, uprisings and local rivalries. Thousands of Muslims perished in the defense of oligarchic interests. The Bangsamoro had their own government and they were already engaged in trade and diplomatic relations with other countries (Tan, 1977: 58). They had developed well organized administrative and political systems; and strong maritime and infantry forces that defended the Bangsamoro territories from Western colonial intrusion, preserving the continuity of their independence (Linga, 2004; Junker, 2000).

With the Spanish invasion of Southern Philippines, the traditional Bangsamoro political system was disrupted which consequently led to revolts and bloody confrontations. Power in Muslim traditional society was (and to some extent still is) reckoned in terms of the number of followers a leader had. To achieve political rank is to have the ability to attract followers. High birth assured social distinction but not political power. It was even possible for one of very low birth to acquire power. Everyone has access to political power (Gowing, 1983: 41). Thus, basically, the problem involves the conflict between the traditional social and political patterns of the Muslims and the new constitutional patterns or 'modern government' imposed by their Spanish colonizers (Gowing, 1983: 43).
The Bangsamoro people insist that Mindanao and the rest of the Southern Philippines had never been under the sovereignty and control of Spain. In spite of Spain's massive and relentless attack against the Muslims, and in spite of the fact that it had penetrated some parts of Mindanao by the use of superior military power which resulted in the fall of Jolo, the strongest center of Moro power in 1876, Spain's victory was never permanent and complete. There was a unified body politic outside the Spanish colonial hegemony from which the Philippine state emerged. Bangsamoro political activists assert their dynastic realms are more fundamental than the contemporary nation-state itself (Mastura, 2007: 76).

The imposition of the American colonial rules and policies had further displaced Islamic laws and polarized interests and loyalties among different Muslim tribes, clans and communities which consequently prevented them as a people from forging a unified resistance against their colonizers. It also fueled internal conflicts and rivalries among Muslim leaders and communities. The interventions of the American colonial government in Muslim internal conflicts allowed them to initiate and preserve the "divide and conquer" policy in relation to Muslim societies (Tan, 1977: 4). The American colonizers had in the process reduced traditional leaders to virtual impotence (Tan, 1977: 20).

The Americans, with more superior and devastating military power had further emasculated the datuship and sultanate's political power and made political compromise more urgent. By the first decade of American rule, Muslim leadership had become divided- one faction continuing the anti-colonial struggle and the other accepting the new option of compromise in a liberal democracy. With the Sultanate's political collapse (who were only allowed to retain their spiritual power), the Muslims lost the political influence they had enjoyed for centuries (Tan, 1993: 9). 
The integration of the Christian Filipino leadership into the American colonial administration's democratic structure as active partner exacerbated the Muslims' frustrations in the struggle to recover their lost power. This meant that the Muslims had not only lost power to the Americans but also to the Christian Filipinos, a political reality whose psychological impact on Muslim consciousness would find its expression in the expansion of the Muslim struggle to include the campaign against the Christian Filipino leadership (Tan, 1993: 10).

Other than their historical experience in state formation, the Bangsamoro people cite political discrimination and oppression they have suffered from the Republic of the Philippines. The biases and prejudices of the Christian majority population towards the Muslims; the minoritization of the Bangsamoro in their own homeland, failure of the government to provide adequate social services have caused untold sufferings among the Muslim populace in Mindanao and resulted in the establishment of revolutionary Islamic organizations fighting for freedom and independence of the Moro people (Cojuangco, 1989; Gowing, 1983: 43). Bishop Quevedo views the cause of the conflict as injustice. It is "injustice to Moro identity; injustice to Moro political sovereignty; and injustice to Moro integral development. He concludes that it is this just and fundamental Moro aspiration for freedom that must be at the heart of all political negotiations for a lasting peace" (Quevedo, 2003).

\section{Economic}

The Spanish and American colonial regimes had caused tremendous effects in the economic life of the Moro people. Earlier, the Spaniards' intrusion in Mindanao had disrupted and destroyed the flow of trade between Muslims and outside traders which adversely affected the economic life of the Moro people. The Spaniards knew that Mindanao had trade connections with Malacca, Borneo and the Moluccas. Obviously, they wanted to cut the Brunei political and economic influences, control the trade and stop Brunei Sultanate from exacting tribute in areas under Spanish control. So, as Mckenna points out, while there is an undeniable religious motive behind the conquest, there is more evidence to show that the objective was mainly to "monopolize trade, controlling resources, and collecting tribute (McKenna, 1988: 82).

Jubair contends that "Spain came to the Philippines not so much for the cross, but in most instances, as facts of her actuations were gradually exposed, religion was merely used to justify what otherwise was a Satanic lust for worldly gain and glory" (Jubair, 1999: 39). Scott corroborates the same view by insisting that "the cross followed commerce and not vice versa, and that Kings and Emperors would accordingly outfit expensive expeditions and sacrifice their subjects' lives not out of religious fanaticism but out of hope for gain." He further insists that, "Spanish-Muslim relations would therefore be characterized not by hatred of Islam but by love of profit (Scott, 1994: 112).

The breakdown in their once robust economic system has reduced many Muslims to extreme poverty indignity and exploitation. This problem was further aggravated when the Americans opened the gates of Mindanao to Christian migrants from Luzon and the Visayas which eventually led to the loss of the Moro people's ancestral land. The QuirinoRecto colonization Act of 1935 encouraged Christian settlement of the South by opening large tracts of land in Mindanao to Christian settlers with government assistance in cash and materials. In 1936, Common wealth Act no. 75 was approved. It abolished the Bureau of non-Christian Tribes and replaced it with the Office of the Commissioner for Mindanao and Sulu giving Christian Filipinos more economic benefits and more influence in Muslim areas (Tan, 1977: 67).

Taxation hardened Muslim opposition to the government. It deprived datus of old privileges and sources of wealth. Muslims also viewed it as a symbol of submission and never as a reciprocal responsibility 
of the governed to the government. They considered taxation as an obligation of the weak and the subordinate. In contrast, they regarded religious levies and those imposed by the Muslim ruling class as proper because they were in accordance with God's decrees and with customary laws. Paying taxes to foreigners was therefore contrary to God's will and tradition (Tan, 197736-37).

The major bone of contention is land. The Muslim Filipinos occupy most of the finest and incredibly fertile land in Mindanaoargued as Ancestral land. But much of these lands had been marked off by the Philippine government for resettlement by non-Muslims from Luzon and the Visayas to alleviate population and land pressures. Muslims resented the Government's parceling out land they feel belongs to them, and failing to win their case in the courts they have on numerous occasions resorted to arms and violence (Rasul, 1979: 26).

The continued armed conflict in Mindanao has also severely affected the economic conditions of the Moro people. Because of the conflict people are deprived of productive economic activities that could have facilitated economic progress. Lives are destroyed, communities and families torn apart, cultures decline and investment is foregone or deflected. Studies have shown that the 10 bottom provinces with the lowest per capita income, the highest poverty incidence, and the worst standard of living are found in predominantly Muslim areas in Mindanao (Philippine Human Development Report on Peace, Human Security and Human Development in the Philippines, 2005).

The Marginalization and discrimination of Muslims by the government and by the majority Christian Filipinos has also prevented them access to education, gainful employment and equal economic benefits. Prejudices and negative stereotypes of Muslims have also affected the delivery of basic social services to depressed areas in Mindanao, thus contributing significantly to their economic woes. The present Aquino government in spite of its flagship job creation program, the Public Private Partnership (PPP), has failed to generate massive employment opportunities to alleviate poverty in Mindanao (Gowing, 1964: 29).

\section{Ethno-Cultural}

Hatred and prejudices between Christians and Muslims had been enforced and institutionalized during the colonial rule. The term "Moro" which Spanish colonialism created from pre-conceived notions carried all the negative sentiments and attitudes of western civilization against primitive societies particularly the Muslims in the South. Based on Spanish sources, the general framework of Spanish historiography on the "Moros" was anchored on two impressions: (1) that the "Moros", as the colonial sources called them, were a degraded race of savages whose only ambition was to plunder, guided strongly by a religion based on the teaching of a false prophet which they called "Muhammedanism;" (2) that their lack of civilization underlined the need to subjugate and civilize them through Christianization (Gowing, 1964: 29).

The term "Moro" was used to refer to the Islamized inhabitants of the archipelago, whose level of culture or civilization was conceived as "primitive" or below western concepts of human progress. All undesirable aspects of human behavior were associated with this level and the specific point of historical reference was the Spanish memory and perception of 7 centuries of Moorish rule in Spain, and from which the term Moro was derived. The term connotescultural depravity, inferiority, and deficiency. The Americans adopted the same perception although they believe that however the Moros were prone to savagery and violence on account of lack of civilization and influence of Islam, they were nevertheless capable of learning the ways of civilized society if given the opportunity through the gradual democratization of their life and institutions (Gowing, 1964: 29).

In general, the American colonial framework is based on the assumption of Muslims' lack of civilization requiring 
subjugation, conquest, and socialchangeeither through outright conversion to Christianity or through gradual democratization.

General Samuel S. Summer who commanded troops in Mindanao and Sulu declared:

“...it will be necessary to eradicate about all the customs that have heretofore governed the Moro's habits of life. They are an essentially different people from us in thought, word and action and their religion will be a serious bar to any efforts towards Christian civilization. So long as Mohammedanism prevails, Anglo-Saxon civilization will make slow headway (Gowing, 1979: 36).

The Filipinization program from 1913 to the end of American rule in 1946 had widened more the cultural gap between Muslims and Christians. Primarily, Filipinization was aimed towards the inculcation of the majority Filipino culture, the eradication of Islamic culture (which was viewed as "counterproductive "and therefore, an "obstacle" in the way of progress) and finally, the mainstreaming and integration of "cultural minorities" to the Philippine republic with a view that it could resolve the seemingly endless conflict and realize peace and development in Mindanao. Steps taken by Christian Filipinos to solve the Muslim problem during the civil regime indicated an increasing influence of the theory that Filipinization and Christianization was the only way to stop Muslim resistance (Tan, 1977: 67).

Quite to the contrary, after 1913, Muslim response to colonial repressive measures against rebelling elements and violations of colonial laws reinforced an anti-Filipino Christian bias which had its origin in the Spanish era when Christian Filipinos were used as soldiers or supporters in the Spanish campaigns. Colonial intrusion and the turning over of the leadership to Christian Filipinos resulted to a crisis of identity. To a large extent the Muslims believed that their Islamic roots were being threatened by the dynamic changes initiated by colonialism and Filipinism. The issue of survival had become more relevant as the Muslims struggled to protect their identity in the light of the change from American to Filipino rule (Tan, 1993: 19).

Filipinism as an ideology was conceived by the Muslims as limited and relevant only to the aspirations of the Christian majority in the country. This brought to a powerful focus the convergence in the Muslim consciousness of their historical losses to colonialism and Filipinism, including the last and most sensitive-their Islamic identity. Many Muslims believe that they are denied of their rights to life, liberty and happiness because they are Muslims (Tan, 1993: 21).

Negative stereotypes against Muslims were opposed by Muslim sources whose framework is anchored on the premise that "Muslim Islamic traditions prove the existence of a civilized society which has utilized armed struggle, however savage it might have been, to preserve Muslim history and culture" (Tan, 2003: 4). The imposition and institutionalization of foreign cultures was conceived by the Muslims as an assault to their Islamic identity and a grave threat to the survival of Islam in Mindanao. For Muslims, defense of their faith and culture is a sacred duty and a fulfillment of God's will.

\section{Religious}

The long years of Spanish missionary activities toward Hispanization and Christianization of Muslims in Mindanao had created deep schisms and religious prejudices between Christian and Muslim inhabitants of Mindanao. To see the religious and theological elements in the conflict, it is important to remember as Cayongcat suggests, that the "Spanish colonization of the Philippines was motivated and inspired by the European religious imperialism that insists on Christianity as the only true religion and the only way by which all men and women could be saved (Cayongcat, 1986: 21). John Schumacher's findings also reveal that the expansion of the Spanish Empire was motivated in part by "an overflow of the 
crusading spirit" which drove out the Moros from the Iberian Peninsula in 1492. Thus, it appears that the Spanish conquest of the Philippines was a product of a rigid religious crusading zeal to "bring the life of the Gospel to the infidels in the newly discovered lands" (Schumacher, 1987: 21).

Mission work and Evangelization of Muslims in Mindanao through the establishment of churches, sectarian schools, hospitals, relief and aid ministries, translation of Bibles to Muslim dialects, were meant to Christianize and shape up the attitudes and values of the Muslims along Christian lines. This religious motive was clearly spelled out in the Jesuits Missionary Letters to Mindanao (Arcilla, 1979: 30). With these, Catholicism was seen as indispensable part of the whole system of colonization. The establishment of Spanish sovereignty and the spread of Catholicism were seen by many Muslims as inseparable union of the Colonizers and the Catholic Church.

Michael Mastura observes that "if anything was imbedded in the mind of the Moros, it was the fact that they became acquainted with Christianity through the methods of reduction and pacification campaigns" launched by the Spaniards against them. Mastura (1976: 8) Against this claim, Soriano contends that a distinction between Spanish colonization and Christianization should be made for the reason that the Roman Catholic Church religion outlived Spanish colonialism and because "even if the Church had been part of the Spanish Imperialist scheme, it rose above the level of Spanish colonialism" (Soriano, 1999: 146).

The same can almost be said about the Americans. The doctrine of "Manifest Destiny" - a conviction that God works for the good of the nations, and that the United States was the "primary agent of God's meaningful activity in history" (Smylie, 1963: 314) served as a theological justification for the American conquest of the Philippines. This concept of manifest destiny as Anderson observes was anchored on the assumption of the superior status of America being the center of human civilization and being the dispenser of "benevolent" benefits to the less fortunate (Anderson, 1969: 280).

Borlado points out that the American conquest of the Philippines was by and large, a product of the "paranoia" of the Western culture which assumes that there is only one universal and normative culture by which all cultures must be judged namely, the Western culture and religion (borlado, 1996). Threatened by the loss of their religious and cultural identity and traditional power, the sultans, local datus and chieftains met the political challenge posed by Christianity by also rallying their people behind Islam, often portraying confrontations with the Spaniards and Americans as a jihad or holy war (Canoy, 1987: 30-32).

\section{CONCLUSION}

As shown in the study, the roots of the conflict in Mindanao can be summarized in four key elements (without prejudice to other elements that might have also contributed to the problem) namely: (1) Historical systematic domination; (2) Political domination and inferiorization (3) Economic marginalization and destitution; and; (4) Threatened Moro and Islamic identity (cultural and religious) (Tan, 1977: 12-30).

The historical experiences of colonization and foreign domination which led to defeats, losses, and humiliations have weighed heavily on the Muslim mind. Added to this is widespread and deep poverty, inequitable distribution of wealth, and control over resources, poor governance as seen in poor delivery of basic social services, corruption in government bureaucracy, political injustice, structural inequities and other forms of injustice and oppression that they have suffered in the hands of their colonizers and the Philippine government. The Moro people have been longing for the recovery of their lost causes and the restoration of their dignity and worth as a people. 
To sum up, the Bangsamoro political struggle is geared towards recognition of their political sovereignty, the implementation of a just social order, the transformation of unjust political structures and the recognition of their Islamic culture and identity (Tan, 1977: 101). The overlaying of modern state structures over the Islamic bases of government as laid down in Islamic shari'ah norms, the annexation of Mindanao and Sulu in the course of decolonization from the United States, and the injustice and marginalization that they have suffered from Christianized Filipinos has not ceased to upset the Bangsamoro people.

The approaches to the Moro struggle have followed three historical options namely: integration, secessionism, and separatism, with the government consistently pursuing the integrationist alternative through the nationalization and Filipinization of the Muslim life and society, and until recently, the advocacy of regional autonomy as a compromise. But failure to substantially implement real autonomy has encouraged the development of Moro secessionist or separatist tendencies (Tan, 1977: 98).

In general, the Philippine government has consistently maintained its integrationist policy to maintain its so-called "territorial integrity" against secessionism and in consonance with constitutional provisions and requirements. Muslims on the other hand believe that they have the right to self-determination and the implementation of this fundamental right to determine their political status will certainly open a window of opportunity to resolve the longdrawn conflict peacefully. They insist that constitutional and institutional barriers cannot be used as excuses to deny the Bangsa Moro people this right (Linga, 2005: 36).

Emran Mohamad insists that "the challenge to the present Philippine government administration is to think outside of the box and that includes amending the Philippine constitution as a new formula in addressing the Bangsamoro people's demand for self-determination"
(Interview with Emran G. Mohamad, Senior Labor and Employment Officer of the Department of Labor and Employment in the Autonomous Region for Muslim Mindanao (DOLE-ARMM), Member of the Board of Trustees of Montana Development Program Incorporated (MDPI) and Member of the Working Committee during the formal opening of the GRP-MILF Peace Talks in 1999, Date of interview: 15 January, 2011).

The government has not made concrete actions to address the aspirations of the poor and marginalized majority Muslim masses. Instead, it caters to the whims and caprices of the Muslim powerful elites who are taking advantage of their positions at the expense of the weak, and therefore, privileging only the dominant segment of society. The dominance of the powerful and the marginalization of the poor and powerless has been the pattern of relationship that characterizes the Philippine society. In this case, the Moro struggle must be understood from below (the underside of Moro history), from the very core of the poor and struggling Muslim and other indigenous communities not from the macro perceptions of the Philippine government's national interests and the Moro liberationists' political agenda.

The government's lukewarm support and indecisiveness to implement an equitable and effective peace agreement also hampered the peace process. There is no coherent and consistent policy on the part of the government on how armed conflict in Mindanao is supposed to be addressed. One example of this incoherence and inconsistencies is the "all-out war policy of President Estrada in 2000 which was reversed to an "all-out peace" policy by President Arroyo in 2001, only to revert back to "allout war" policy in 2002-2003 (Hernandez, 2005). These inconsistencies are inevitably destroying the credibility of the government.

Another problem as cited by Bacani is the "bystander mentality" of Christian political elites in Mindanao "whose hold on political and economic power is threatened by any settlement." These are local "political 
leaders and groups that have substantial economic interests in continuing the armed conflict, who benefit legitimately or otherwise from large budgets in times of war," and who will accept a peace agreement as long as it involves "only the Muslims and the existing autonomous region" and as long as the agreement "does not exact even an inch of concession from the Christian majority (Bacani, 2005).

The Philippine government's militaristic and repressive approaches to armed conflict based on the belief that rebellion and insurgencies are best handled through decisive military response, has resulted to further resistance and retaliation resulting to social and economic dislocation. Powerful interests also stand to benefit from it, not the least of whom are some groups in the military and politicians for whom opportunities for corruption increase with bloated war appropriations. Those who stand to benefit from a war have an interest in provoking it or manipulating "events on the ground" (UNDP, 2005: 33).

The pacification and demobilization approaches employed by the government which seeks to address the conflict by cooptation of leaders and followers through the offer of positions, or livelihood, or integration has left the deeper roots of the conflict unaddressed. One prominent example of this practice of cooptation of Muslim leaders in exchange for lucrative benefits which have been a consistent formula in many administrations was the appointment of Nur Misuari as governor of ARRM. This practice has been described as "oiling" or "greasing" only the parts of the machine that squeak, without regard for the corrosion of the rest.

On the Muslims' side, remedies toward the resolution of the conflict have been forwarded and widely discussed among different Islamic organizations and institutions but no substantial unity has been achieved yet. Within and among Moro leadership and communities, there are divergent perspectives and agenda that further complicate the problem. For instance, while the nationalist MNLF leadership opens up for negotiations towards expanded and genuine autonomy in Muslim Mindanao, the Islamist MILF leadership has firmly maintained its demand for independence and separation from the Philippine body politics. Islamists can be categorized as "Muslims who feel compelled to act on the belief that Islam demands social and political activism, to create a separate union for Muslim communities." Religion in this sense can be said to "animate nationalism" by providing meaning and intelligibility for Muslim minorities (Hafez, 2004: 3-5).

In the same vein of thought, Sayyid refers to Islamists as "those who use the language of Islamic metaphors to think through their political destinies, those who see in Islam their political future (Sayyid, 2003). The vision of a separate Islamic state, Syukri observes is "predicated not only on perceived religious injunctions that Muslims need to live within a state defined with reference to their religion, but also on the notion that such entity existed in a territorial form in the past and predated the creation of the modern nation-state by Western enterprise of colonialism" (Syukri, 1985). The MILF's main objective is to "make supreme the word of Allah and establish Islam in the Bangsamoro homeland" (McKenna, 1998: 208).

Factionalism in Muslim leadership was said to have been exploited to serve the interest of the government. In that sense, they were no better than power brokers of the old political order as they remained to be the only channel of access to the top. Consequently, majority of the Muslim masses showed very little support in the currents of political actions they espoused. As it appears, the current Moro armed conflict as described by the United Nations' Development program (UNDP) is "the sharpest expression of the clash between two imagined nations or nationalisms, Filipino and Moro, each with their own narrative of the conflict" (Philippine Human Development Report, 2005) and each with their own version of 
solution to the problem. For the Moro people, it is a matter of rectifying the long-standing political injustice that they have suffered in the hands of the Philippine government. For the Philippine nation-state, it is a matter of defending its territorial integrity against secessionism. In sum, the conflict is "a veritable case of irresistible forces, and immovable objects" (UNDP, 2005: 65).

Amina Rasul believes that the current conflict in Mindanao is "not between Muslims and Christians, but rather between an oppressed minority and a largely indifferent government." (Rasul, 2011). Obviously, power and resources are concentrated in the hands of a few political elites (including religious elites) while the masses (mostly Muslims) are being pushed to the periphery of human existence. The ties of traditional Muslim elite leadership with the central government has kept the Muslim struggle within what the central government perceived as "controllable level" and has deprived the Moro masses of their right to self-determination. This is the context in which the Moro people's demands for freedom and independence should be understood.

\section{BIBLIOGRAPHY}

Abinales, Patricio, 2000, Making Mindanao: Cotabato and Davao in the Formation of the Philippine Nation-State, Manila: Ateneo de Manila University Press.

Anderson, Gerard H, 1969, Studies in Philippine Church History, New York: Cornell University Press.

Ankersen, Christopher (ed.), 2007, Understanding Global Terror, Cambridge, UK: Polity Press

Arcilla, Jose, 1979, Jesuits Mission Letters from Mindanao, Quezon City: Ateneo de Manila University Press.

Bacani, Benedicto R. Bacani, 2005, The Mindanao peace talks: Another Opportunity to Resolve the Moro Conflict in the Philippines, Volume 31, Issues 20-131, United States Institute of Peace.
Canoy, Reuben, 1987, The Quest for Mindanao Independence, Cagayan de Oro City: Mindanao Post Publishing Company

Cayongcat, Al-Rashid I, 1986, Bangsa Moro People in Search of Peace, Manila: Foundation for the Advancement of Islam in the Philippines.

Man, W.K. Che,1990, Muslim Separation: The Moros of the Philippines and the Malays of Southern Thailand, Quezon City: Ateneo de Manila University Press.

Gaerlan, Kristina and Mara Stankovitch (eds.), 2000, Rebels, Warlords and Ulama: A Reader on Muslim Separatism and the War in Southern Philippines, Quezon City: Institute for Popular Democracy.

Gowing, Peter Gordon, 1964, Mosque and Moro: A Study of Muslims in the Philippines. Manila: Philippine Federation of Christian Churches

1983, Mandate in Moro Land: The American Government of Muslim Filipinos 1899-1920, Quezon City: New Day Publishers

Gowing, Peter G. and Robert D. McAmis (Eds.), 1974, The Muslim Filipinos, Manila: Solidaridad Publishing House

Gutierrez, Eric, 2000, "Religion and Politics in Muslim Mindanao," in Kristina Gaerlan and Mara Stankovitch (eds.), Rebels, Warlords and Ulama: A Reader on Muslim Separatism and the War in Southern Philippines, Quezon City: Institute for Popular Democracy.

Hafez, Mohammed M. 2004, Why Muslims Rebel: Repression and Resistance in the Islamic World, Boulder: Lynne Rienner

Haar, Gerrie terr and James J. Busuttil (eds.), 2005, Bridge or Barrier: Religion, Violence and Visions for Peace, Leiden, Boston: Brill

Jubair, Salah, 1999, The Bangsamoro: A Nation under Endless Tyranni, Kuala Lumpur: IQ Marin. 
Krishna, Kumar Rama and See Seng Tan (Eds.), 2003, After Bali the Threat of Terrorism in Southeast Asia, Singapore: World Scientific

LaRousse, William, 2001, Walking Together Seeking Peace: The Local Church of Mindanao-Sulu Journeying in Dialogue with the Muslim Community 1965-2000, Quezon City: Claretian Publications.

Laubach, Frank, 1925, The People of the Philippines, Manila: George H. Doran Company.

Linga, Abhoud Syed M, 2005, “Bangsamoro Self-determination", in Voices from Moroland, 36

Majul, Cesar Adib, 1999, Muslims in the Philippines, Quezon City: University of the Philippines Press

Mastura, Michael, 2007, "Political Islam in the $21^{\text {st }}$ Century Philippines: Can It Survive?" in Voices from the Moroland,

McKenna, Thomas M, 1998, Muslim Rulers and Rebels: Everyday Politics and Armed Separatism in the Southern Philippines, Manila: Anvil Publishing

Mendoza, Everett, 1999, Radical and Evangelical: Portrait of a Filipino Christian, Quezon City,

Philippines: New Day Publishers.

Mercado, Leonardo N, 2009, Dialogue and Faith: A Philippine View, Philippines: Logos Publications Inc.

Mitsuo, Nakamura et al. (Eds.), 2001, Islam and Civil Society in Southeast Asia, Singapore: Institute of Southeast Asian Studies.

Nathan, K.S. and Mohammad Hashim Kamali (eds.), 2005, Islam in Southeast Asia, Singapore: Institute of Southeast Asian Studies

NICA, 1996, "Briefing on Terrorism," briefing paper prepared by the Philippine National Intelligence Coordinating Agency (NICA), January 1996,
Osais, C and Lorenza, 1931, Evangelical Christianity in the Philippines, Philippines: United Brethren Publishing House

Philippine Human Development Report on Peace, Human Security and Human Development in the Philippines (2005), Published by the Human Development Network (HDN), United Nations Development Program (UNDP) and New Zealand Agency for International Development (NZAID).

Philippine Human Development Report, 2005, Report to the United Nations Development Program (UNDP), Manila, Philippines: UNDP.

Quevedo, Bishop Orlando B, 2003, “Injustice: The Root of the Conflict in Mindanao," a Paper presented at the $27^{\text {th }}$ General Assembly and Annual Meeting of the Bishops Business Men's Conference, Fort Bonifacio Global City, Taguig, Metro Manila, July 8.

Sayyid, S, 2003, A Fundamental Fear: Eurocentrism and the Emergence of Islamism, London: Zed Books.

Rasul, Jainal, 1979, Muslim-Christian Land: Ours to Share, Quezon City: AlemarPhoenix Publishing Co., Inc.

Rasul, Amina, 2011, Lecture on "Prospects of Peace and Development in Mindanao," 14 February 2011 at the Colegio de San Juan de Letran (CSJL), San Juan Metro Manila, Philippines

Scott,William Henry, 1994, Crusade or Commerce?: Spanish-Moro Relations in the $16^{\text {th }}$ Century, Quezon City: Ateneo de Manila University Press

Schumacher, John, 1987, Readings in the Philippine Church History, $2^{\text {nd }}$ edition,. Quezon City: Loyola School of Theology. 
Syukri, Ibrahim, 1985, History of the Malay Kingdom of Pattani, Translated by C. Bailey \& J. Miksic, Athens: Center for International Studies.

Tan, Samuel K, 1977, The Filipino Muslim Armed Struggle 1900-1972, Makati: Filipinos Foundation

------, 1993, Internationalization of the Bangsamoro Struggle, Quezon City: The Center for Integrative and Development Studies and the University of the Philippines Press
------, 2003, Filipino Muslim Perceptions of their History and Culture as Seen Through Indigenous Sources, Zamboanga City: SKT Publications Series.

Turner, Mark R J May and Lulu Respall Turner (eds.), 1992, Mindanao, Land of Unfulfilled Promise, Quezon City, Philippines: New Day Publishers.

Vitug, Marites Danguilan and Glenda M. Gloria, 2000, Under the Crescent Moon: Rebellion in Mindanao, Manila: Institute for Popular Democracy and Ateneo Center for Social Policy and Public Affairs 